\title{
Nuts and Body Weight - An Overview
}

\section{Lutz $\mathrm{M}^{*}$ and Luna $\mathrm{L}$}

Centro de Investigación y Desarrollo de Alimentos Funcionales, Escuela de Química y Farmacia, Universidad de Valparaíso, Gran Bretaña 1093, Valparaíso, Chile

${ }^{*}$ Corresponding author: Lutz M, Centro de Investigación y Desarrollo de Alimentos Funcionales, Escuela de Química y Farmacia, Universidad de Valparaíso, Gran Bretaña 1093, Valparaíso, Chile, Tel: +56 322508418 , E-mail: mariane.lutz@uv.cl

Citation: Lutz M, Luna L (2016) Nuts and Body Weight - An Overview. J Nutr Health Sci 3(1): 104. doi: $10.15744 / 2393-9060.3 .104$

\section{Received Date: January 07, 2015 Accepted Date: February 23, 2016 Published Date: February 25, 2016}

\begin{abstract}
Since obesity and overweight became health issues, tree nuts became considered as unhealthy, due to their high fat content. Their high energy density has been pointed as a major factor in body weight gain. However, nuts have been part of the traditional diet in many geographical areas for centuries and in the last decades various laboratory assays, as well as epidemiological and clinical studies, substantiate that the regular intake of nuts is not a relevant factor influencing body lipid accumulation. This paper describes various mechanisms of action proposed to explain the effect of nuts on the regulation of body weight that are currently under examination.
\end{abstract}

Keywords: Nuts; Body weight; Obesity; Chronic diseases; Nutrition

\section{Introduction}

Energy homeostasis is a highly complex process that has not been completely understood. In subjects chronically exposed to a high fat intake, the regulatory mechanisms for body weight maintenance are lost. Lipids accumulate in the abdominal zone and adipokines secretion by adipocytes is altered [1]. Lipids also accumulate in metabolically active tissues such as liver, muscle, and pancreas, all of which constitute the basis for the development of metabolic syndrome (MetS) [2].

\section{Historical evidence on the nutritional benefits of consumption of nuts}

Nuts are fruits composed of a hard shell and a seed, which is generally edible. In a botanical context, they are indehiscent, since the shell does not open to release the seed, although the term often refers to any hard-walled, edible kernel as a nut. Tree nuts have been a major part of the human diet around the world for millennia. The remains of seven types of 780,000-year-old nuts were found at the Gesher Benot Yaaqov site in the Dead Sea rift, in Israel [3]. The nuts and the stone tools found with them demonstrate that nuts formed a major part of the diet of prehistoric humans and that they had developed various tools to crack open nuts during the Early-Middle Pleistocene [3]. In fact, cracking nuts is a subsistence activity of contemporary hunter-gatherer societies worldwide, as substantiated by extensive data on the taxonomy, seasonality, gathering, cracking, consumption, and nutritional value of nuts. "Nutting stones" which archeologists date back 4,000 to 8,000 years have been found in the United States and Europe, where ancient Romans gave sugared almonds as gifts at weddings, a custom still used today in some regions [4]. According to Brufau, et al., nuts originate from Anatolia [5]. From there, the cultivation of tree nuts was introduced in Greece, then in Italy during the Roman Empire, and finally it was extended to all of Europe during the Middle Ages.

The origins of the "Mediterranean Diet" are lost in time; however, they are related to the eating habits of the Middle Ages, in which the ancient Roman tradition identified bread, wine and oil products as symbols of their culture. The traditional Mediterranean diet includes a high intake of vegetables, legumes, fruits, nuts, and cereals; high to moderate intake of fish; moderate to low intake of dairy products; low intake of red meats, and moderate intake of red wine. This represents a low intake of saturated fatty acids and high intake of unsaturated fatty acids. Tree nuts are part of this dietary pattern and the most commonly consumed include almonds, hazelnuts, walnuts, pine nuts, pistachios, macadamia, and cashews [6]. Although not real nuts, peanuts (a legume) are usually included in this group [7].

\section{Nuts intake and chronic diseases}

Nuts contain high levels of fats and proteins, theoretically providing a range of 550 to $750 \mathrm{kcal} / 100 \mathrm{~g}$, so they are high energy density foods (Table 1). Because of this, nuts became considered as unhealthy; however, in the last decades their nutritional value is being re-recognized. In spite of being energy dense foods, nut intake has been associated with the reduction of risk factors of chronic diseases. Epidemiological evidence indicates that people consuming five servings or more of nuts per week do not weigh 
more than people who consume less than one serving of nuts per week [8]. This is of major importance, since overweight, obesity and related chronic diseases constitute serious public health problems and a high proportion of individuals are attempting to maintain or reduce their BMI, and the roles dietary nuts play to accomplish this goal have to be acknowledged. Some of the mechanisms by which nuts may influence body weight are presented.

\begin{tabular}{|c|c|c|c|c|c|c|}
\hline \multicolumn{2}{|c|}{} & \multicolumn{3}{c|}{ Fatty acids } \\
\hline Type of nut & Proteins & Lipids & Fiber & $\mathbf{S}^{1}$ & $\mathbf{M I}^{\mathbf{2}}$ & PI $^{3}$ \\
\hline Cashew & 18.22 & 43.85 & 3.3 & 7.783 & 23.797 & 7.845 \\
\hline Pine nut & 13.69 & 68.37 & 3.7 & 4.899 & 18.764 & 34.071 \\
\hline Macadamia & 7.91 & 75.77 & 8.6 & 12.061 & 58.877 & 1.502 \\
\hline Pistachio & 20.16 & 45.32 & 10.6 & 5.907 & 23.257 & 14.380 \\
\hline Almond & 21.15 & 49.93 & 12.5 & 3.802 & 31.551 & 12.329 \\
\hline Hazelnut & 14.95 & 60.75 & 9.7 & 4.464 & 45.652 & 7.920 \\
\hline Pecan & 9.17 & 71.97 & 9.6 & 6.180 & 40.801 & 21.614 \\
\hline Walnut & 15.23 & 65.21 & 6.7 & 6.126 & 8.933 & 47.174 \\
\hline Peanut & 25.80 & 49.24 & 8.5 & 6.279 & 24.426 & 15.558 \\
\hline
\end{tabular}

${ }^{1}$ Saturated; ${ }^{2}$ Monounsaturated; ${ }^{3}$ Polyunsaturated

Table 1: Total proteins, lipids, fiber and fatty acids content of raw nuts and peanuts reported in the USDA [67] (g/100 g)

CVD are the first death cause in most developed and developing Western countries. Epidemiologic studies and clinical trials demonstrate that nut consumption has beneficial effects on cardiovascular health, they lower the risk of peripheral arterial disease, type 2 diabetes, inflammation, and a number of risk factors, which could collectively reduce chronic disease [9-18]. The PREDIMED study proved an association between the frequency of nut consumption and mortality risk [19] while van den Brandt and Schouten in a meta-analysis concluded that total nut intake was related to lower overall and cause-specific mortality (cancer, diabetes, cardiovascular, respiratory, neurodegenerative diseases, and other causes), with evidence for nonlinear doseresponse relationships [20]. Similarly, Grosso, et al. in a revision of prospective studies through meta-analysis demonstrated that nut consumption is associated with improvements in a series of risk factors for chronic diseases and lower mortality risk [21].

Several clinical trials indicate that nuts can modulate blood lipids, including total cholesterol, LDL cholesterol, ApoB, and triglycerides [22,23], endothelial function [24], insulin resistance [25,26], and ameliorate glycemic control in patients with diabetes [27]. Mohammadifard, et al. observed that total nut consumption lowered blood pressure in participants without type 2 diabetes [28]. All these situations are involved in the development of MetS, a multifactorial syndrome that represents a cluster of abnormalities, including obesity, insulin resistance, dyslipidemia, and associated comorbidities that increase the risk of developing CVD and leads to substantially increased morbidity of CVD and diabetes mellitus type 2 [29]. Inclusion of nuts as part of a healthy diet is inversely and independently associated with a decreased risk of MetS as well as overall and vascular-disease mortality, particularly in women $[30,31]$.

There is substantial epidemiological and clinical trial evidence supporting that adherence to the Mediterranean diet relates to a reduced prevalence of the MetS [32]. Kastorini, et al. meta-analyzed 50 epidemiological studies and clinical trials concluding that adherence to the Mediterranean dietary pattern was associated with lower MetS prevalence and progress [33]. Blanco Mejia, et al. analyzed 49 reports of randomized controlled dietary trials of tree nuts matched for energy on at least one of the five criteria of the MetS (waist circumference, triglycerides, HDL-cholesterol, blood pressure and fasting blood glucose) [34]. They observed a MetS benefit of tree nuts through modest decreases in triglycerides and fasting blood glucose with no adverse effects on other criteria across nut types. In two cohort studies, nut intake related to reduced total, CVD and cancer and respiratory mortality [35]. These findings support recommendations to consume tree nuts alone or as part of heart healthy dietary patterns as a mean for improving metabolic control.

\section{Nuts intake and body weight}

In 2003, Sabaté reported an association between nut consumption and body weight [36]. Results of the EPIC (European Prospective Investigation into Cancer) multicenter, prospective cohort study investigating the role of metabolic, dietary, lifestyle, and environmental factors in the development of chronic diseases indicated that a high adherence to the Mediterranean diet may reduce the likelihood of gaining weight and becoming overweight or obese after 5 y of follow-up [37]. Since then, evidence has accumulated, and ten years later Ibarrola-Jurado, et al. reported in a cohort of the PREDIMED study that nut consumption was inversely associated with the prevalence of general obesity, central obesity, MetS, and diabetes in subjects at high cardiovascular risk [38]. 
Since several years, evidence shows an association between nut consumption and body weight including cross-sectional and prospective epidemiologic studies that indicate an inverse association between the frequency of nut consumption and BMI (kg/ $\mathrm{m}^{2}$ ) and risk of obesity [8,25,36-51]. Casas-Agustench, et al. reported that results of multivariate analyses with adjustment for various confounders showed that nut intake was the sole dietary component consistently and inversely associated with adiposity measures [50]. In a meta-analysis of clinical trials, Flores-Mateo, et al. concluded that compared with control diets, diets enriched with nuts did not increase body weight, BMI, or waist circumference [51]. Besides, individuals who consume nuts regularly tend to eat less red meat and refined carbohydrates, and such a replacement that may be beneficial for the prevention of weight gain.

\section{Nuts intake and appetite}

The intake of almonds and peanuts suppresses hunger and desire to eat and increases fullness ratings after ingestion [52-54]. Various mechanisms have been involved to explain the effects of nut consumption on body weight [55]. The sensory, nutrient, and/ or physical properties of tree nuts and peanuts affect gut hormone secretion and appetitive responses by consumers: nuts induce satiation (reduction in the total amount of food eaten in a single meal) and satiety (reduction in the frequency of meals) [56-58]. Satiety is induced mainly by two gut hormones: cholecystokinin (CCK) and glucagon like peptide 1 (GLP-1). CCK is released from duodenal entero-endocrine cells into the blood stream in response to fatty acids or protein, while GLP-1 is produced in the ileum, induced by passing fatty acids (FA) and carbohydrates both playing major roles in food intake control as satiety hormones [59]. Besides, both CCK and GLP-1 release lead to a delay in gastric emptying, early satiety and a decrease in food consumption [60].

Chain length and the degree of saturation of the FA influence the satiating effect of fats. Only FA with chain lengths $\geq \mathrm{C} 12$, as those prevailing in tree nuts, are capable of reducing food intake and releasing CCK and GLP-1 [61], being long-chain FA more effective than medium-chain FA [62]. Another mechanism that may be involved in the effect of nuts on weight gain is that their fat quality determines the thermogenic response to this fatty food $[63,64]$. Comparing the effect of two Mediterranean diets versus a low-fat diet Lasa, et al. observed increased values of the adipokines adiponectin to leptin ratio and decreased values of waist circumference, associated with a significant reduction in body weight for a nuts diet, which were not significant for a low-fat diet [65].

While the oil content of most nuts ranges from 44 to $76 \mathrm{~g} / 100 \mathrm{~g}$, nuts are also a good source of dietary plant protein, ranging from nearly 8 to $26 \mathrm{~g} / 100 \mathrm{~g}[10,66,67]$. They also contain variable amounts of fiber, both known to increase the satiety of meals and prolong feelings of fullness following consumption (Table 1).

\section{Mastication and available energy}

Nuts contain high levels of fats, and are considered as high energy density foods. Nevertheless, Baer, et al. observed that the available energy from various nuts might be $9 \%-32 \%$ less than that predicted by the Atwater factors [68]. The digestibility of a given nut is nut-dependent, and since mastication affects the digestibility it is possible that different nuts elicit different amounts of chewing [58]. Various studies have evaluated the efficiency of energy absorption from tree nuts and peanuts through feeding trials, showing substantive increases in fecal fat loss with nut consumption [23,58]. Healthy subjects consuming $76 \mathrm{~g}$ of peanuts for $4-6$ days excreted $18 \%$ of dietary fat per day and the stools contained intact portions of the nuts. This fat malabsorption was observed both when high and low-fiber diets containing whole peanuts were evaluated [69].

The physicochemical structure of lipid storing granules as well as various nut fiber components do not allow complete release of fatty acids during digestion, affecting fat absorption $[25,70]$. The inefficiency may be attributed to the resistance of the parenchymal cell walls of nuts to microbial and enzymatic degradation, passing through the gastrointestinal tract affecting the bioaccesibility of lipids and proteins. Another complimentary explanation for the less energy provided by a diet containing nuts is that the majority of the energy nuts provide is offset by spontaneous adjustments in the total diet $[71,72]$.

Satiety may be induced by the fact that nuts intake require increased mastication [52]. Kirkmeyer, et al. observed that the satiating effects of nuts depend on their form: when peanuts are consumed as butter the induction of hunger suppression is lower and there is a greater hunger rebound (180 min post-ingestion) compared with whole nuts. In fact, chewing generates more potent satiation signals through various mechanisms $[58,73,74]$.

The intake of almonds with a meal does not affect the appetite-modulating effects of that meal, whereas consuming almonds alone (as snacks) blunts hunger and desire-to-eat ratings [75]. Mechanical disruption of the parenchymal cell walls of nuts liberates the lipid and protein they contain in their matrix, promoting the release of intestinal peptide hormones that induce satiety [41]. An incomplete mastication of nuts is common and leads to increased fecal losses of lipids and proteins [50]. Hutchings, et al. observed that the physical properties of nuts influence their disintegration characteristics, so that the matrix in which they are embedded modifies chewing behavior, although without modifying the final nut particle size [76]. 
Among the nutrients of the Mediterranean diet, FA from olive oil, fish and nuts seem to modulate brain serotonin pathway, which may influence eating behavior [77]. Binge eating disorder implies the consumption of a large amount of food in a discrete period, with an associated sense of loss of control in the absence of regular compensatory behavior intended to prevent weight gain, such as vomiting or laxative abuse, which is also among the causes of weight gain. Bertoli, et al. postulated that olive oil and nut consumption are associated with less diagnosis of this disorder [78].

\section{Nut oil}

Nuts are energy-dense foods mainly because they contain 44 to $74 \mathrm{~g} / 100 \mathrm{~g}$ oil $[8,10,79,80]$. However, nut consumption improves blood lipid levels and reduce risk factors of CVD [81,82]. The cardio-protective constituents include unsaturated FA, phytosterols, tocopherols, and squalene [83-86]. The lipid fraction contains various tocopherols $(\alpha-, \gamma-$, and $\delta$-tocopherol) at remarkably high levels [87]. In 2002, the U.S. Food and Drug Administration approved a qualified health claim for tree nuts, which stated "Scientific evidence suggests, but does not prove, that eating 1.5 ounces per day of most nuts as part of a diet low in saturated fat and cholesterol may reduce the risk of heart disease" [88]. The types of nuts eligible for this claim are restricted to almonds, hazelnuts, peanuts, pecans, pine nuts, pistachios, and walnuts, that is, nuts that do not exceed $4 \mathrm{~g}$ saturated fat per $50 \mathrm{~g}$. To date, various countries have health claims approved stating the health benefits afforded by tree nuts (including USA, Canada, and Spain).

Oleic acid (18:1n-9) is the prominent monounsaturated FA (MUFA) in most nut types, while polyunsaturated (PUFA) linoleic (18:2n-6) and $\alpha$-linolenic (18:3n-3) acids are also represented [10]. While most tree nuts show a higher content of MUFA, pine nuts exhibit a FA profile in which PUFA are more abundant, prevailing linoleic acid [79,80,85,86,89].

Pine nut oils contains a unique class of unsaturated FA, the $\Delta 5$-unsaturated polymethylene-interrupted pinolenic acid (18:3$\Delta 5,9,12)$, found in Pinus koraiensis (11-15\%), Pinus pinaster (7\%), Pinus cembroides edulis (0.36\%), and Pinus pinea (0.0-0.37\%) [84,87,90-95]. This FA may suppress appetite by acting on CCK release [96]. Pasman, et al. observed that feeding $3 \mathrm{~g}$ of pine nut oil (as FA or triglycerides of Pinus koraiensis) decreased prospective food-intake ratings and increased the secretion of CCK [56]. Korean pine nut oil FA were approximately 8 -fold more potent in releasing CCK than other pine nut oils FA, an effect attributed to pinolenic acid since the contents of other unsaturated FA is similar between pine nuts from different species.

Both a possible increment in resting energy expenditure and in fat oxidation have been described for nuts. In fact, consumption of pinolenic oil reduced weight gain in obese mice maintained on a high fat diet [97]. Le, et al. observed that this FA markedly reduced triglyceride accumulation in the muscles of mice exposed to a high-fat diet by activating the mitochondrial oxidative pathway [98]. The authors observed that pinolenic acid upregulated UCP1 transcription and expression in brown adipose tissue, that is, genes involved in the regulation of thermogenesis, mitochondrial biogenesis and oxidative metabolism. These findings led to the commercialization of a nutraceutical directed towards weight control, containing Korean pine nut with $92 \%$ free FA and triglycerides (PinnoThin ${ }^{\mathrm{Tw}}$ ) [99]. However, in a clinical double blind, randomized, crossover design study, Verhoef and Westerterp concluded that a dosage of $6 \mathrm{~g}$ PinnoThin ${ }^{\mathrm{ms}}$ triglycerides is not sufficient to suppress appetite sensations and energy intake [100]. But when a health claim was applied for, the European Food Safety Agency (EFSA) Regulatory Expert Panel concluded that a cause and effect relationship has not been established between the consumption of "pine nut oil from Pinus koraiensis Siebold \& Zucc." and a sustained increase in satiety leading to a reduction in energy intake [101]. This situation reflects the importance of eating whole foods (nuts) in their natural food matrix, containing all the nutrients and bioactives that may act synergistically to provide the beneficial health effects.

At the time, no claim on the association of nuts intake on body weight management has been approved, and a study is ongoing to conduct a series of systematic reviews and meta-analyses of the totality of the evidence from controlled trials and prospective cohort studies to investigate the effect of nut consumption on body weight and adiposity [102].

\section{Concluding remarks}

The substantial evidence for the beneficial role of nuts in risk reduction of non-chronic diseases has led to the development of public health recommendations (in the form of Dietary Guidelines or others) to include nuts regularly in the diet for general healthy eating. Moreover, there is a trend toward higher nut consumers being leaner than non-nut consumers. The effects of nuts on the regulation of body weight are currently under examination, including the various mechanisms that may be involved in this action.

It is important to consider that tree nuts and peanuts represent a variety of complex food matrices containing nutrients and bioactive compounds, and the beneficial effects of frequent nut consumption may be attributed to the synergistic action of these constituents, so a variety of these dietary seeds is recommended.

\section{Acknowledgements}

This project was funded by Centro de Investigación y Desarrollo de Alimentos Funcionales (CIDAF), Escuela de Química y Farmacia, Dirección de Investigación de la Universidad de Valparaíso, Chile. 


\section{References}

1. Leibowitz SF, Chang GC, Dourmashkin JT, Yun R, Julien C, et al. (2006) Leptin secretion after a high-fat meal in normal-weight rats: strong predictor of longterm body fat accrual on a high-fat diet. Am J Physiol Endocrinol Metab 290: E258-67.

2. McPherson R, Jones PH (2003) The metabolic syndrome and type 2 diabetes: role of the adipocyte. Curr Opin Lipidol 14: 549-53.

3. Goren-Inbar N, Sharon G, Melamed Y, Kislev M (2002) Nuts, nut cracking, and pitted stones at Gesher Benot Ya'aqov, Israel. Proc Natl Acad Sci U S A 99: 2455-60.

4. Nutcracker Museum, Bavarian Leavenworth, Washington.

5. Brufau G, Boatella J, Rafecas M (2006) Nuts: source of energy and macronutrients. Br J Nutr 96: S24-8.

6. King JC, Blumberg J, Ingwersen L, Jenab M, Tucker KL (2008) Tree nuts and peanuts as components of a healthy diet. J Nutr 138: 1736S-40S.

7. Arya SS, Salve AR, Shauhan S (2016) Peanuts as functional food: a review. J Food Sci Technol 53: 31-41.

8. Natoli S, McCoy P (2007) A review of the evidence: nuts and body weight. Asia Pac J Clin Nutr 16: 588-97.

9. Hu FB, Willett WC (2002) Optimal diets for prevention of coronary heart disease. JAMA 288: 2569-78.

10. Ros E, Mataix J (2006) Fatty acid composition of nuts-implications for cardiovascular health. Br J Nutr 96: S29-35.

11. Salas-Salvadó J, Bulló M, Pérez-Heras A, Ros E (2006) Dietary fibre, nuts and cardiovascular diseases. Br J Nutr 96: S46-51.

12. Ros E (2015) Nuts and CVD. Br J Nutr 113: S111-20.

13. Heffron SP, Rockman CB, Gianos E, Guo Y, Berge JS (2015) Greater frequency of nut consumption is associated with lower prevalence of peripheral arterial disease. Prev Med 72: 15-8.

14. Jiang R, Manson JE, Stampfe MJ, Liu S, Willett WC, et al. (2002) Nut and peanut butter consumption and risk of type 2 diabetes in women. JAMA 288: 2554-60. 15. Jenkins DJ, Hu FB, Tapsell LC, Josse AR, Kendall CW (2008) Possible benefit of nuts in type 2 diabetes. J Nutr 138: 1752S-56S.

16. Jiang R, Jacobs DR Jr, Mayer-Davis E, Szklo M, Herrington D, et al. (2006) Nut and seed consumption and inflammatory markers in the multi-ethnic study of atherosclerosis. Am J Epidemiol 163: 222-31.

17. Casas-Agustench P, Bulló M, Salas-Salvadó J (2010) Nuts, inflammation and insulin resistance. Asia Pac J Clin Nutr 19: 124-30.

18. Brown RC, Tey SL, Gray AR, Chisholm A, Smith C, et al. (2015) Association of nut consumption with cardiometabolic risk factors in the 2008/2009 New Zealand adult nutrition survey. Nutrients 7: 7523-42.

19. Guasch-Ferre M, Bulló M, Martínez-González MA, Ros E, Corella D, et al. (2013) Frequency of nut consumption and mortality risk in the PREDIMED nutrition intervention trial. BMC Medicine 11: 164.

20. van den Brandt PA, Schouten LJ (2015) Relationship of tree nut, peanut and peanut butter intake with total and cause-specific mortality: a cohort study and meta-analysis. Int J Epidemiol 44: 1038-49.

21. Grosso G, Yang J, Marventano S, Micek A, Galvano F, et al. (2015) Nut consumption and all-cause, cardiovascular, and cancer mortality risk: A systematic review and meta-analysis of epidemiologic studies. Am J Clin Nutr 101: 783-93.

22. Mukuddem-Petersen J, Oosthuizen W, Jerling JC (2005) A systematic review of the effects of nuts on blood lipid profiles in humans. J Nutr 135: 2082-9.

23. Del Gobbo LC, Falk MC, Feldman R, Lewis K, Mozaffarian D (2015) Effects of tree nuts on blood lipids, apolipoproteins, and blood pressure: systematic review, meta-analysis, and dose-response of 61 controlled intervention trials. Am J Clin Nutr 102: 1347-56.

24. Casas-Agustench P, López-Uriarte P, Ros E, Bulló M, Salas-Salvadó J (2011) Nuts, hypertension and endothelial function. Nutr Metab Cardiovasc Dis 1: S2133.

25. García-Lorda P, Megias Rangil I, Salas-Salvadó J (2003) Nut consumption, body weight and insulin resistance. Eur J Clin Nutr 1: S8-11.

26. Kendall CW, Josse AR, Esfahani A, Jenkins DJ (2010) Nuts, metabolic syndrome and diabetes. Br J Nutr 104: 465-73.

27. Jenkins DJ, Kendall CW, Banach MS, Srichaikul K, Vidgen E, et al. (2011) Nuts as a replacement for carbohydrates in the diabetic diet. Diabetes Care 34: 1706-11.

28. Mohammadifard N, Salehi-Abargouei A, Salas-Salvadó J, Guasch-Ferré M, Humphries K, et al. (2015) The effect of tree nut, peanut, and soy nut consumption on blood pressure: a systematic review and meta-analysis of randomized controlled clinical trials. Am J Clin Nutr 101: 966-82.

29. Grundy SM, Brewer HB Jr, Cleeman JI, Smith SC Jr, Lenfant C, et al. (2004) Definition of the Metabolic Syndrome: Report of the National Heart, Lung, and Blood Institute/ American Heart Association Conference on Scientific Issues Related to Definition. Circulation 109: 433-8.

30. Estruch R, Martínez-González MA, Corella D, Salas-Salvadó J, Ruíz-Gutiérrez V, et al. (2006) Effects of a Mediterranean-style diet on cardiovascular risk factors: a randomized trial. Ann Intern Med 145: 1-11.

31. Gopinath B, Flood VM, Burlutksy G, Mitchel P (2015) Consumption of nuts and risk of total and cause-specific mortality over 15 years. Nutr Metab Cardiovasc Dis 25: 1125-31.

32. Esposito K, Giugliano D (2010) Mediterranean diet and the metabolic syndrome: the end of the beginning. Metab Syndr Relat Disord 8: 197-200.

33. Kastorini CM, Milionis HJ, Esposito K, Giugliano D, Goudevenos JA, et al. (2011) The effect of Mediterranean diet on metabolic syndrome and its components: a meta-analysis of 50 studies and 534,906 individuals. J Am Coll Cardiol 57: 1299-313.

34. Blanco Mejia S, Kendall CWC, Viguiliouk E, Augustin LS, Ha V, et al. (2014) Effect of tree nuts on metabolic syndrome criteria: a systematic review and metaanalysis of randomized controlled trials. Br Med J Open 4: e004660.

35. Bao Y, Han J, Hu FB, Giovannucci EL, Stampfer MJ, et al. (2013) Association of nut consumption with total and cause-specific mortality. N Eng J Med 369: 2001-11.

36. Sabaté J (2003) Nut consumption and body weight. Am J Clin Nutr 78: 647S-50S.

37. Romaguera D, Norat T, Vergnaud AC, Mouw T, May AM, et al. (2010) Mediterranean dietary patterns and prospective weight change in participants of the EPIC-PANACEA project. Am J Clin Nutr 92: 912-21.

38. Ibarrola-Jurado N, Bulló M, Guasch-Ferré M, Ros E, Martínez-González MA, et al. (2013) Cross-sectional assessment of nut consumption and obesity, metabolic syndrome and other cardiometabolic risk factors: The PREDIMED Study. PLoS One 8: e57367. 
39. Shai I, Schwarzfuchs D, Henkin Y, Shaha, DR, Witkow S, et al. (2008) Weight loss with a low-carbohydrate, Mediterranean, or low-fat diet. N Eng J Med 359: 229-41.

40. Schroeder H, Marrugat J, Vila J, Covas MI, Elosua R (2004) Adherence to the traditional Mediterranean diet is inversely associated with body mass index and obesity in a Spanish population. J Nutr 134: 3355-61.

41. Mattes RD, Kris-Etherton PM, Foster GD (2008) Impact of peanuts and tree nuts on body weight and health weight loss in adults. J Nutr 138: 1741S-45S.

42. Bes-Rastrollo M, Sabaté J, Gómez-Gracia E, Alonso A, Martínez JA, et al. (2007) Nut consumption and weight gain in a Mediterranean cohort: The SUN study. Obesity 15: 107-16.

43. Beunza JJ, Toledo E, Hu FB, Bes-Rastrollo M, Serrano Martínez M, et al. (2010) Adherence to the Mediterranean diet, long-term weight change, and incident overweight or obesity: the Seguimiento Universidad de Navarra (SUN) cohort. Am J Clin Nutr 92: 1484-93.

44. Mozaffarian D, Hao T, Rimm EB, Willett WC, Hu FB (2011) Changes in diet and lifestyle and long-term weight gain in women and men. N Eng J Med 364: 2392-404.

45. Issa C, Darmon N, Salameh P, Maillot M, Batal M, et al. (2011) A Mediterranean diet pattern with low consumption of liquid sweets and refined cereals is negatively associated with adiposity in adults from rural Lebanon. Int J Obesity 35: 251-8.

46. Vadivel V, Kunyanga CN, Biesalski HK (2012) Health benefits of nut consumption with special reference to body weight control. Nutrition 28 : $1089-97$.

47. Jackson CL, Hu FB (2014) Long-term associations of nut consumption with body weight and obesity. Am J Clin Nutr 408S-11S.

48. O’Neil CE, Fulgoni VL, Nicklas TA (2015) Tree nut consumption is associated with better adiposity measures and cardiovascular and metabolic syndrome health risk factors in U.S. Adults: NHANES 2005-2010. Nutr J 14: 64.

49. Martínez-González MA, Bes-Rastrollo M (2011) Nut consumption, weight gain and obesity: Epidemiological evidence. Nutr Metab Cardiovasc Dis 1: S40-5.

50. Casas-Agustench P, Bulló M, Ros E, Basora J, Salas-Salvadó J, et al. (2011) Cross-sectional association of nut intake with adiposity in a Mediterranean population. Nutr Metab Cardiovasc Dis 21: 518-25.

51. Flores-Mateo G, Rojas-Rueda D, Basora J, Ros E, Salas-Salvadó J (2013) Nut intake and adiposity: meta-analysis of clinical trials. Am J Clin Nutr 97: $1346-55$.

52. Brennan AM, Sweeneym LL, Lium X, Mantzoros CS (2010) Walnut consumption increases satiation but has no effect on insulin resistance or the metabolic profile over a 4-day period. Obesity (Silver Spring) 18: 1176-82.

53. Tan SY, Mattes RD (2013) Appetitive, dietary and health effects of almonds consumed with meals or as snacks: a randomized, controlled trial. Eur J Clin Nutr 67: 1205-14.

54. Mori AM, Considine RV, Mattes RD (2011) Acute and second-meal effects of almond form in impaired glucose tolerant adults: a randomized crossover trial. Nutr Metab 8: 6.

55. Mattes RD, Dreher ML (2010) Nuts and healthy body weight maintenance mechanisms. Asia Pac J Clin Nutr 19: $137-41$.

56. Pasman WJ, Heimerikx J, Rubingh CM, Berg R, O’Shea M, et al. (2008) The effect of Korean pine nut oil on in vitro CCK release, on appetite sensations and on gut hormones in post-menopausal overweight women. Lipids Health Dis 7: 10.

57. Reis CE, Ribeiro DN, Costa NM, Bressan J, Alfenas RC, et al. (2013) Acute and second-meal effects of peanuts on glycaemic response and appetite in obese women with high type 2 diabetes risk: a randomised cross-over clinical trial. Br J Nutr 109: 2015-23.

58. Cassady BA, Hollis JH, Fulford AD, Considine RV, Mattes RD (2009) Mastication of almonds: Effects of lipid bioaccessibility, appetite, and hormone response. Am J Clin Nutr 89: 794-800.

59. Maljaars J, Romeyn EA, Haddeman E, Peters HPF, Masclee AAM (2009) Effect of fat saturation on satiety, hormone release, and food intake. Am J Clin Nutr 89: 1019-24.

60. Strader AD, Woods SC (2005) Gastrointestinal hormones and food intake. Gastroenterology 128: 175-91.

61. Feltrin KL, Little TJ, Meyer JH, Horowitz M, Smout AJ, et al. (2004) Effects of intraduodenal fatty acids on appetite, antropyloroduodenal motility, and plasma CCK and GLP-1 in humans vary with their chain length. Am J Physiol - Regul Integr Compar Physiol 287: R524-33.

62. McLaughlin J, Luc MG, Jones MN, D’Amato M, Dockray GJ, et al. (1999) Fatty acid chain length determines cholecystokinin secretion and effect on human gastric motility. Gastroenterology 116: 46-53.

63. Casas-Agustench P, López-Uriarte M, Bulló E, Ros A, Gómez-Flores J, et al. (2009) Acute effects of three high-fat meals with different fat saturations on energy expenditure, substrate oxidation and satiety. Clin Nutr 28: 39-45.

64. Casas-Agustench P, López-Uriarte M, Bulló E, Ros A, Cabré-Vila JJ, et al. (2011) Effects of one serving of mixed nuts on serum lipids, insulin resistance and inflammatory markers in patients with the metabolic syndrome. Nutr Metab Cardiovasc Dis 21: 126-35.

65. Lasa A, Miranda J, Bulló M, Casas R, Salas-Salvadó J, et al. (2014) Comparative effect of two Mediterranean diets versus a low-fat diet on glycaemic control in individuals with type 2 diabetes. Eur J Clin Nutr 68: 767-72.

66. Alasalvar C, Shahidi F (2008) Tree Nuts: Composition, Phytochemicals, and Health Effects. Nutraceutical Science and Technology Series, CRC Press, Boca Raton.

67. US Department of Agriculture (2015) National Nutrient Database for Standard Reference, Release 28. Nutrient Data Laboratory Home Page.

68. Baer DJ, Gebauer SK, Novotny JA (2016) Walnuts consumed by healthy adults provide less available energy than predicted by the Atwater factors. J Nutr 146: $9-13$.

69. Levine AS, Silvis SE (1980) Absorption of whole peanuts, peanut oil, and peanut butter. N Eng J Med 303: 917-18.

70. Ellis PR, Kendall CW, Ren Y, Parker C, Pacy JF, et al. (2004) Role of cell walls in the bioaccessibility of lipids in almond seeds. Am J Clin Nutr 80: 604-13.

71. Tan SY, Dhillon J, Mattes RD (2014) A review of the effects of nuts on appetite, food intake, metabolism, and body weight. Am J Clin Nutr 100: 412S-22S.

72. Grundy M, Grassby T, Mandalari G, Waldron K, Butterworth PJ, et al. (2015) Effect of mastication on lipid bioaccessibility of almonds in a randomized human study and its implications for digestion kinetics, metabolizable energy, and postprandial lipemia. Am J Clin Nutr 101: 25-33.

73. Kirkmeyer SV, Mattes RD (2000) Effects of food attributes on hunger and food intake. Int J Obes Relat Metab Disord 24: 1167-75.

74. Forde CG, van Kuijk N, Thaler T, de Graaf C, Martin N (2013) Oral processing characteristics of solid savoury meal components and relationship with food composition, sensory attributes and expected satiation. Appetite 60: 208-19. 
75. Zaveri S, Drummond S (2009) The effect of including a conventional snack (cereal bar) and nonconventional snack (almonds) on hunger, eating frequency, dietary intake and body weight. J Hum Nutr Diet 22: 461-8.

76. Hutchings SC, Foster KD, Bronlund JE, Lentle RG, Jones JR, et al. (2011) Mastication of heterogeneous foods: peanuts inside two different food matrices. Food Qual Pref 22: 332-9.

77. Sánchez-Villegas A, Delgado-Rodríguez M, Alonso A, Schlatter J, Lahortiga F, et al. (2009) Association of the Mediterranean dietary pattern with the incidence of depression. The Seguimiento Universidad de Navarra/University of Navarra Follow-up (SUN) Cohort. Arch Gen Psychiatry 66: 1090-8.

78. Bertoli S, Spadafranca A, Bes-Rastrollo M, Martínez-González MA, Ponissi V, et al. (2015) Adherence to the Mediterranean diet is inversely related to binge eating disorder in patients seeking a weight loss program. Clin Nutr 34: 107-14.

79. Ryan E, Galvin K, O'Connor TP, Maguire AR, O’Brien NM (2006) Fatty acid profile, tocopherol, squalene and phytosterol content of Brazil, pecan, pine, pistachio and cashew nuts. Int J Food Sci Nutr 57: 219-28.

80. Kornsteiner-Krenn M, Wagner KH, Elmadfa I (2013) Phytosterol content and fatty acid pattern of ten different nut types. Intl J Vit Nutr Res 83: 263-70.

81. Sabaté J, Oda K, Ros E (2010) Nut consumption and blood lipid levels: a pooled analysis of 25 intervention trials. Arch Int Med $170: 821-7$.

82. Kris-Etherton PM, Hu FB, Ros E, Sabaté J (2008) The role of tree nuts and peanuts in the prevention of coronary heart disease: multiple potential mechanisms. J Nutr 138: 1746S-51S.

83. Wolff RL, Bayard CC (1995) Fatty acid composition of some pine seed oils. J Am Oil Chem Soc 72: 1043-46.

84. Wolff RL, Marpeau AM (1997) $\Delta 5$-olefinic acids in the edible seeds of nut pines (Pinus cembroides edulis) from the United States. J Am Oil Chem Soc 74: 613-14.

85. Bolling BW, Chen CY, McKay DL, Blumberg JB (2011) Tree nut phytochemicals: composition, antioxidant capacity, bioactivity, impact factors. A systematic review of almonds, Brazils, cashews, hazelnuts, macadamias, pecans, pine nuts, pistachios and walnuts. Nutr Res Rev 24: 244-75.

86. Alasalvar C, Bolling BW (2015) Review of nut phytochemicals, fat-soluble bioactives, antioxidant components and health effects. Br J Nutr 113: S68-S78.

87. Nasri N, Khaldi A, Fady B, Triki S (2005) Fatty acids from seeds of Pinus pinea L.: Composition and population profiling. Phytochemistry 66: $1729-35$.

88. US Food and Drug Administration. Summary of Qualified Health Claims Subject to Enforcement Discretion.

89. Miraliakbari H, Shahidi F (2008) Lipid class compositions, tocopherols and sterols of tree nut oils extracted with different solvents. J Food Lipids 15: 81-96.

90. Nergiz C, Donmez I (2004) Chemical composition and nutritive value of Pinus pinea L. seeds. Food Chem 86: 365-8.

91. Venkatachalam M, Sathe SK (2006) Chemical composition of selected edible nut seeds. J Agric Food Chem 54: 4705-14.

92. Evaristo I, Batista D, Correia I, Correia P, Costa R (2010) Chemical profiling of Portuguese Pinus pinea L. nuts. J Sci Food Agric 90: $1041-9$.

93. Lutz M, Alvarez K, Loewe V (2016) Chemical composition of pine nuts (Pinus pinea L.) grown in three geographical macrozones in Chile. Int J Food Sci Nutr. 94. Yoon TH, Im K, Koh ET, Ju JS (1989) Fatty acid compositions of Pinus koraiensis seed. Nutr Res 9: 357-61.

95. Robbins KS, Shin EC, Shewfelt RL, Eitenmiller RR, Pegg RB (2011) Update on the healthful lipid constituents of commercially important tree nuts. J Agric Food Chem 59: 12083-92

96. Frantisek Z, Meuselbach K (2010) Effect of Pinus koraiensis seed oil on satiety hormones CCK and GLP-1 and appetite suppression. Translat Biomed 1: 5.

97. Park S, Lim Y, Shin S, Han SN (2013) Impact of Korean pine nut oil on weight gain and immune responses in high-fat diet-induced obese mice. Nutr Res Pract 7: $352-8$.

98. Le NH, Shin S, Tu TH, Kim CS, Kang JH, et al. (2012) Diet enriched with Korean pine nut oil improves mitochondrial oxidative metabolism in skeletal muscle and brown adipose tissue in diet-induced obesity. J Agric Food Chem 60: 11935-41.

99. Hughes GM, Boyland EJ, Williams NJ, Monnen L, Scott C, et al. (2008) The effect of Korean pine nut oil (PinnoThin ${ }^{\mathrm{Tx}}$ ) on food intake, feeding behaviour and appetite: A double-blind placebo-controlled trial. Lipids Health Dis 7: 6.

100. Verhoef SPM, Westerterp KR (2011) No effects of Korean pine nut triacylglycerol on satiety and energy intake. Nutr Metab 8: 79.

101. EFSA Panel on Dietetic Products, Nutrition and Allergies (NDA) (2011) Scientific Opinion on the substantiation of a health claim related to "pine nut oil from Pinus koraiensis Siebold \& Zucc" and an increase in satiety leading to a reduction in energy intake (ID 551) pursuant to Article 13(1) of Regulation (EC) No 1924/2006. EFSA J 9: 2046.

102. Sievenpiper J (2016) Nuts in relation to markers of adiposity, overweight, and obesity: A series of systematic reviews and meta-analyses of randomized controlled trials and prospective cohort studies.

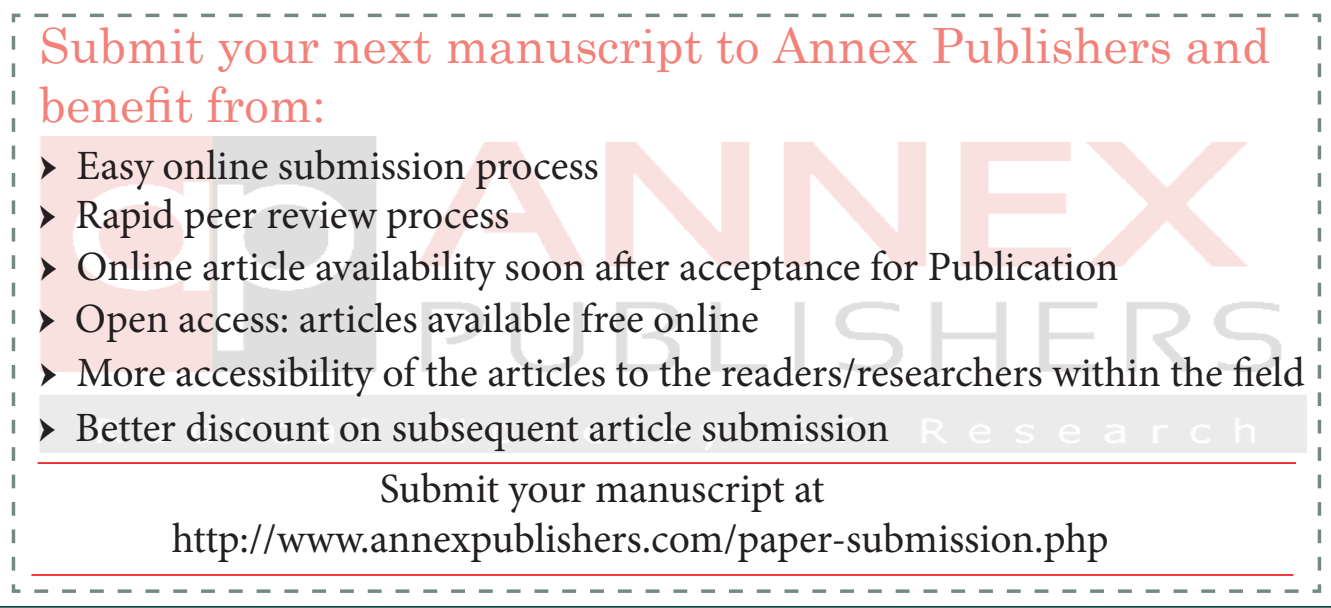

